\title{
MEASURING TOURISTS' SATISFACTION WITH QUALITY OF LIFE ISSUES AT AN ARTS FESTIVAL
}

\author{
S Kruger \& D Petzer, School of Business Management, North-West University, South Africa
}

Purpose: The purpose of this paper is to measure tourists' satisfaction with quality of life issues at an arts festival - the Aardklop National Arts Festival in Potchefstroom.

Problem investigated: Understanding satisfaction with quality of life issues could assist Festival organizers and other businesses to improve services for tourists by tailoring these to meet their needs. Satisfied tourists spread positive wordof-mouth communication and are more likely to return in the future.

Methodology: A self-administered survey developed and validated by Neal, Sirgy and Uysal (1999:156 \& 2004:245) was fielded at the 2007 Aardklop National Arts Festival in Potchefstroom. The target population included all visitors to the Festival who were staying for two or more days, and who had travelled to Potchefstroom from elsewhere.

Findings and implications: Respondents were satisfied with travel/tourism services and experiences at the Festival, and with their leisure time and life in general. However, certain things at the Festival led to lowered levels of satisfaction. Demographically, respondents did not differ significantly in their levels of satisfaction with travel/tourism services, travel/tourism experiences, leisure life, and life in general at the Festival except in terms of population group and region from which they came.

Organizers of the Festival and other businesses should take cognizance of the fact that all parties involved in providing services to tourists attending an arts festival impact on their satisfaction levels with travel/tourism services and experiences - and ultimately also on their quality of life. Tourists attending the arts festival are not homogenous and differ substantially in terms of their demographic profile. Tourist service providers should tailor their offerings in order to satisfy the varied needs of the different types of tourist attending the Festival.

Originality and value of the research: This research focused on measuring tourists' satisfaction with quality of life issues at an arts festival. Such research has never before been conducted in South Africa; the results contribute to the deeper insight of interested parties (such as the tourism industry and arts festival managers) into what they need to offer at such events.

Key words and phrases: quality of life, events, tourism services, satisfaction levels, service quality, services marketing.

\section{INTRODUCTION}

It is commonly understood that attending an arts festival gives tourists a chance to take a break from everyday life, to do with their leisure time what they will - in short, to experience freedom from the pressures of life, and bring home good memories of their trip. Attending an arts festival could have a positive impact on the tourist's quality of life provided that he or she is satisfied with the various services and experiences on offer at such a festival. Understanding such perceptions could assist festival organizers and other festival businesses to improve the experiences of tourists - thereby making sure that tourists return, thus benefiting business as well.

This paper examines tourists' satisfaction with tourism services, tourism experiences, leisure life and life in general, while travelling to, and attending, the Aardklop National Arts Festival.

\section{PURPOSE AND OBJECTIVES}

The purpose of the paper is to measure, at Aardklop, tourists' satisfaction levels with quality of life issues. The paper has the following objectives:

- To determine a demographic profile of tourists attending Aardklop.

- To determine respondents' levels of satisfaction with travel/tourism services at Aardklop. 
- To determine respondents' levels of satisfaction with travel/tourism experiences at Aardklop.

- To determine respondents' levels of satisfaction with their leisure life.

- To determine respondents' levels of satisfaction with life in general.

- To determine whether people from different demographic groups differ in their levels of satisfaction with travel/tourism services, travel/tourism experiences, their leisure life, and life in general.

\section{THEORETICAL BACKGROUND}

This section of the paper puts the Aardklop Arts Festival in perspective. It also addresses the model, suggested by Neal, Sirgy and Uysal (1999:156 \& 2004:245), that is used to measure the effect of tourism services and experiences on a tourist's quality of life.

\section{Tourism and Arts Festivals}

Major events such as arts festivals are one of the fastest-growing segments in the tourism industry in South Africa. Travelling to arts festivals is becoming a very popular way of spending leisure time. Ryan (1991:436) describes vacation tourism as the means by which people seek the psychological benefits that arise from experiences found in new places, and, while in new situations, however temporary, are free from the onerous constraints of work, or the normal, repetitive, patterns of daily life. Attending an arts festival can be classified as vacation tourism. An arts festival can best be described as a community-themed event or celebration designed to showcase different art forms and events - along with the related tourism and hospitality experiences - for external communities.

The Aardklop National Arts Festival takes place in Potchefstroom, South Africa, for five days at the end of September each year. According to Saayman (2007:211-213), Aardklop stages different types of theatre - children's theatre, street theatre, dance theatre, cabaret, and musicals - as well as the visual arts, literature, and music (classical, rock, and jazz).

Aardklop has a major impact on the economy of Potchefstroom: it is estimated that 61476 tourists attended the Festival in 2006, spending R34.5 million (Saayman \& Saayman, 2006:38). Groups of tourists travelling to Aardklop in 2007 spent an average of R2612.55 per group on accommodation, travel, and food. An estimated total of R43.5 million was spent during the Festival in 2007 (Saayman \& Ferreira, 2007:26-28). These figures are indicative of the rapid growth of Aardklop.

The following section examines the effects of tourism services and experiences on a tourist's quality of life.

\section{Tourism Services and Experiences and the Tourist's Quality of Life}

Neal et al. (1999:156 \& 2004:245) suggest a model which indicates the effect of tourism services and experiences on a tourist's quality of life. Their study focuses on determining satisfaction levels in four different components relating to quality of life: satisfaction with travel/tourism services, satisfaction with travel/tourism experiences, satisfaction with leisure life, and satisfaction with life in general (Neal et al., 1999:156 \& 2004:245). Each of these components is discussed below.

\section{Satisfaction with Travel/Tourism Services}

The first component of the model focuses on tourists' levels of satisfaction with the services they receive while on a trip. It is divided into pre-trip, en-route, destination, and return-trip services (Neal et al., 2004:244-245). 


\section{Satisfaction with Travel/Tourism Experiences}

The second component involves the travel experiences of tourists and is described as 'trip reflections'. The model measures satisfaction with travel/tourism experiences in relation to the contribution of the trip to 'perceived freedom of control, perceived freedom from work', 'involvement', 'arousal', 'mastery', and 'spontaneity' (Neal et al., 2004:244-245). These measures of services and experiences are based on Clawson and Knetsch's (1971) five-phase model of travel. The result is a tool to measure satisfaction with leisure experiences and tourism services.

\section{Satisfaction with Leisure Life}

Neal et al. (1999:156 \& 2004:244) state that a tourist's satisfaction with his or her leisure life stems from the tourist being satisfied with travel/tourism experiences as mentioned above - as well as with his or her leisure experiences at home. In a recent study of family life, De Rue, llies, Ilgen, Johnson, Schwind and Wagner (2007:1368-1369) found that behaviours and activities which take place in the family domain (e.g. going to a shopping centre, spending time on a new hobby, visiting an arts festival with family or friends) are very important in sustaining a healthy family life. Activities in which an individual engages, as well as time spent with the family in a social setting, have been proved to have a positive affect on family life (Clark \& Watson, 1988:296-300 and Watson, 2000:340). Khaneman, Kreuger, Schkade, Schwarz and Stone (2004:1777-1779) confirm that individuals experience high levels of positivity and low levels of negativity when they are involved in leisure activities.

\section{Satisfaction with Life in General}

The last component is the tourist's satisfaction with life in general. Neal et al. (2004:255-245) state that this involves satisfaction in 'life domains' such as the tourist's family situation, personal health, and work.

Well-being researchers often distinguish between three components of subjective well-being, as in 'pleasant affect', 'unpleasant affect', and 'life satisfaction' Life satisfaction is always a constituent of quality of life definitions, even in those cases where the latter is quantified in purely functional terms (Bailey, Eng, Frisch \& Snyder, 2007:168-169). Thus life satisfaction can be seen as being a cognitive evaluation - but it is also made up of pleasant experiences, happy relationships with family and friends, contentment with one's health and standard of living. Life satisfaction is determined in a selfevaluation of an individual's likes and dislikes regarding his or her life.

\section{DESIGN/METHODOLOGY/APPROACH}

A self-administered survey was fielded at Aardklop in Potchefstroom in the North West Province of South Africa. The measurement instrument used was developed and validated by Neal, Sirgy and Uysal (1999:156 \& 2004:245).

The phrasing of statements was adapted to suit the context of the particular study. Section A of the survey determined the demographic profile of respondents and included questions about gender, dietary requirements, highest qualifications, population group, and home region. Sections B, C, D and E measured levels of satisfaction on a five-point Likert scale, which ranged from 'strongly disagree' to 'strongly agree'. Section B measured satisfaction with travel/tourism services and focused on 'pre-trip services', 'en route services', 'destination services' and 'return-trip services'. Section C measured 'satisfaction with the travel/tourism experiences' themselves. The questions related to 'perceived freedom from control and work', 'involvement', 'arousal', 'mastery', and 'spontaneity'. Section D examined respondents' 'satisfaction with their leisure life', and Section E measured 'satisfaction with life in general'.

The target population included all visitors to Aardklop staying for two or more days, and who had travelled from out of town. In order to identify the target population, two screening questions were asked of prospective respondents. The first was 'Did you travel from any other city to Potchefstroom?' and the second 'For how many days are you staying in Potchefstroom while attending the Aardklop Arts Festival?' The local population of Potchefstroom were not involved in this survey, as they did not spend time actually travelling to and from the Festival. 
An intercept sampling method was used to select participants. Five field workers were strategically placed on the Festival grounds. Typically, a field worker approached a prospective respondent and determined his or her willingness to participate in the study. If a respondent was willing, the field worker asked the screening questions. If the respondent met the criteria, he or she was asked to complete the survey. The field worker remained available to assist with any questions or queries while the respondent completed the survey. Afterwards, the respondent was thanked. A total of 317 took part in the study.

\section{HYPOTHESES}

The following hypotheses were formulated for the study:

$\mathrm{H}_{1}$ : There is a significant difference between male and female respondents in their levels of satisfaction with quality of life issues.

In order to refine the above hypothesis, the following hypotheses can be formulated:

$\mathrm{H}_{1 \mathrm{a}}$ : There is a significant difference between male and female respondents in their levels of satisfaction with travel/tourism services.

$\mathrm{H}_{1 \mathrm{~b}}$ : There is a significant difference between male and female respondents in their levels of satisfaction with travel/tourism experiences.

$\mathrm{H}_{1 \mathrm{c}}$ : There is a significant difference between male and female respondents in their levels of satisfaction with their leisure life.

$\mathrm{H}_{1 \mathrm{~d}}$ : There is a significant difference between male and female respondents in their levels of satisfaction with life in general.

$\mathrm{H}_{2}$ : There is a significant difference between respondents with different dietary requirements in their levels of satisfaction with quality of life issues.

In order to refine the above hypothesis, the following hypotheses can be formulated:

$\mathrm{H}_{2 \mathrm{a}}$ : There is a significant difference between respondents with different dietary requirements in their levels of satisfaction with travel/tourism services.

$\mathrm{H}_{2 \mathrm{~b}}$ : There is a significant difference between respondents with different dietary requirements in their levels of satisfaction with travel/tourism experiences.

$\mathrm{H}_{2 \mathrm{c}}$ : There is a significant difference between respondents with different dietary requirements in their levels of satisfaction with their leisure life.

$\mathrm{H}_{2 \mathrm{~d}}$ : There is a significant difference between respondents with different dietary requirements in their levels of satisfaction with life in general.

$\mathrm{H}_{3}$ : There is a significant difference between respondents with different qualifications in their levels of satisfaction with quality of life issues.

In order to refine the above hypothesis, the following hypotheses can be formulated:

$\mathrm{H}_{3 a}$ : There is a significant difference between respondents with different qualifications in their levels of satisfaction with travel/tourism services.

$\mathrm{H}_{3 b}$ : There is a significant difference between respondents with different qualifications in their levels of satisfaction with travel/tourism experiences.

$\mathrm{H}_{3 c}$ : There is a significant difference between respondents with different qualifications in their levels of satisfaction with their leisure life. 
$\mathrm{H}_{3 \mathrm{~d}}$ : There is a significant difference between respondents with different qualifications in their levels of satisfaction with life in general.

$\mathrm{H}_{4}$ : There is a significant difference between respondents from different population groups in their levels of satisfaction with quality of life issues.

In order to refine the above hypothesis, the following hypotheses can be formulated:

$\mathrm{H}_{4 \mathrm{a}}$ : There is a significant difference between respondents from different population groups in their levels of satisfaction with travel/tourism services.

$\mathrm{H}_{4 \mathrm{~b}}$ : There is a significant difference between respondents from different population groups in their levels of satisfaction with travel/tourism experiences.

$\mathrm{H}_{4 \mathrm{c}}$ : There is a significant difference between respondents from different population groups in their levels of satisfaction with their leisure life.

$\mathrm{H}_{4 \mathrm{~d}}$ : There is a significant difference between respondents from different population groups in their levels of satisfaction with life in general.

$\mathrm{H}_{5}$ : There is a significant difference between respondents from different regions in the country in their levels of satisfaction with quality of life issues.

In order to refine the above hypothesis, the following hypotheses can be formulated:

$\mathrm{H}_{5 \mathrm{a}}$ : There is a significant difference between respondents from different regions of the country in their levels of satisfaction with travel/tourism services.

$\mathrm{H}_{5 b}$ : There is a significant difference between respondents from different regions of the country in their levels of satisfaction with travel/tourism experiences.

$\mathrm{H}_{5 c}$ : There is a significant difference between respondents from different regions of the country in their levels of satisfaction with their leisure life.

$\mathrm{H}_{5 \mathrm{~d}}$ : There is a significant difference between respondents from different regions of the country in their levels of satisfaction with life in general.

\section{RESULTS}

Before the results obtained from the survey can be analysed, it is necessary to examine the representativity of the sample, as well as the validity and reliability of the measurement sets. Doing so assists in understanding the context in which results should be interpreted. This section also describes the demographic profile of respondents and reports the satisfaction levels for individual statements in each measurement set, as well as the overall mean score for satisfaction for each measurement set. Finally, significant differences between the different groups of respondents are indicated.

\section{Representativity}

The researchers and field workers strictly followed the sample plan, as described in the section on research methodology, in order to ensure the representativity of the sample.

\section{Distribution of Results: Skewness and Kurtosis}

Before the results can be presented, it is necessary to determine whether the results obtained for each of the survey's statements show a normal distribution. The kurtosis and skewness of the results' distribution for each measurement set was examined. An activity for which the skewness of the distribution is less than 2.00 , or where the kurtosis of the distribution is less than 7.00 , falls within acceptable limits of normality (West, Finch \& Curran, 1995:74). All statements included in the 
measurement sets determining satisfaction with travel/tourism services, satisfaction with travel/tourism experiences, satisfaction with leisure life, and satisfaction with life in general, fall within these limits.

\section{Reliability}

Cronbach's alpha was used to determine the reliability of the measurement sets which assess levels of satisfaction with travel/tourism services, satisfaction with travel/tourism experiences, satisfaction with leisure life, and satisfaction with life in general. The measure ranges from 0 to1. A value of 1 indicates perfect reliability, whilst the value of 0.70 is deemed to be the lower level of acceptability (Hair, Anderson, Tatham \& Black, 1998:118). The reliability statistics for the measurement sets are presented in Table 1.

\section{Table 1: Reliability statistics}

\begin{tabular}{|l|c|}
\hline \multicolumn{1}{|c|}{ Measurement sets } & Cronbach's alpha \\
\hline Satisfaction with travel/tourism services (12 items) & 0.913 \\
\hline Satisfaction with travel/tourism experiences (24 items) & 0.901 \\
\hline Satisfaction with leisure life (11 items) & 0.842 \\
\hline Satisfaction with life in general (4 items) & 0.926 \\
\hline
\end{tabular}

It is evident from Table 1 that Cronbach's alpha for all measurements sets is well above the lower limit of acceptability, 0.70 . This confirms that the measurement sets used in the study are reliable.

\section{Validity}

When assessing validity, the researcher determines whether a measure used in the study actually does measure what the researcher intends it to measure. As already indicated, the measurement instrument developed and validated by Neal, Sirgy and Uysal (1999 \& 2004) was used in this study. The instrument was considered valid for the purposes of the present study.

\section{Demographic Profile of Respondents}

Table 2 provides an exposition of the demographics of respondents taking part in the study. It is evident from the table that the majority of respondents were female $(58.7 \%)$ and $41.3 \%$ of respondents were male. The majority of respondents $(66.7 \%)$ did not follow any special diet, while $12.1 \%$ and $12.4 \%$ of respondents followed, respectively, low-fat and low-cholesterol diets. The majority of respondents indicated Grade 12 as their highest qualification, followed by $24.8 \%$ of respondents who had a diploma, and $23.2 \%$ of respondents who had a degree. The majority of respondents were white $(81.9 \%)$, whilst the remaining respondents classified themselves as coloured $(6.7 \%)$, Indian $(6.3 \%)$ and black $(5.1 \%)$. The majority of respondents were from Gauteng $(30.8 \%)$, followed by the North West (23. 5\%) and the Free State (11.1\%).

It can therefore be said that the respondents vary in terms of the diets they follow, their qualifications, the population groups they belong to, and the regions they come from. The respondents are thus not a homogenous group, and different demographics are evident. 
Table 2: Demographic characteristics of respondents

\begin{tabular}{|c|c|c|}
\hline Gender & Frequency & Percentage \\
\hline Male & 130 & 41.3 \\
\hline Female & 185 & 58.7 \\
\hline Total & 315 & 100.0 \\
\hline Dietary requirements & Frequency & Percentage \\
\hline No special diet & 210 & 66.7 \\
\hline Low-fat & 38 & 12.1 \\
\hline Low-cholesterol & 39 & 12.4 \\
\hline Diabetic & 21 & 6.7 \\
\hline Other & 7 & 2.2 \\
\hline Total & 315 & 100.0 \\
\hline Highest qualification & Frequency & Percentage \\
\hline No school & 9 & 2.9 \\
\hline Grade 12 & 114 & 36.2 \\
\hline Diploma & 78 & 24.8 \\
\hline Degree & 73 & 23.2 \\
\hline Postgraduate & 27 & 8.6 \\
\hline Professional & 6 & 1.9 \\
\hline Less than grade 12 & 8 & 2.5 \\
\hline Total & 315 & 100.0 \\
\hline Population group & Frequency & Percentage \\
\hline Black & 16 & 5.1 \\
\hline Coloured & 21 & 6.7 \\
\hline Indian & 20 & 6.3 \\
\hline White & 258 & 81.9 \\
\hline Total & 315 & 100.0 \\
\hline Region & Frequency & Percentage \\
\hline North-West & 74 & 23.5 \\
\hline Mpumalanga & 22 & 7.0 \\
\hline Limpopo & 17 & 5.4 \\
\hline Gauteng & 97 & 30.8 \\
\hline Kwa-Zulu Natal & 19 & 6.0 \\
\hline Eastern Cape & 11 & 3.5 \\
\hline Western Cape & 32 & 10.2 \\
\hline Free State & 35 & 11.1 \\
\hline Northern Cape & 8 & 2.5 \\
\hline Total & 315 & 100.0 \\
\hline
\end{tabular}


Levels of Satisfaction with Travel/Tourism Services, Travel/Tourism Experiences, Leisure Life, and Life in General

This section reports on the results obtained for individual statements in each of the four measurement sets included in the survey. The mean, top-box score, low-box score and standard deviation are reported for each statement. The last part of this section provides the overall mean scores calculated for each measurement set.

Table 3 provides an exposition of the levels of satisfaction for individual statements which indicated satisfaction with travel/tourism services. The statement 'Tourist services provided at the destination ... These services made the trip a richer experience' obtained the highest mean score (4.22), followed by 'Tourist services provided at the destination were basically problem-free ...' (4.15). The lowest mean score, 3.79, was for the statement 'I was satisfied with the quality of the services provided by those who assisted me on the way home'.

Table 3: Satisfaction with travel/tourism services

\begin{tabular}{|l|c|c|c|c|c|}
\hline \multicolumn{5}{|c|}{ Satisfaction with travel/tourism services } \\
\hline \multicolumn{1}{|c|}{ Activity } & N & Mean & $\begin{array}{c}\text { Top-box } \\
\text { score }\end{array}$ & $\begin{array}{c}\text { Low-box } \\
\text { score }\end{array}$ & $\begin{array}{c}\text { Standard } \\
\text { deviation }\end{array}$ \\
\hline $\begin{array}{l}\text { I was satisfied with the quality of service } \\
\text { provided by tourism professionals (e.g. travel } \\
\text { agents, booking agents, reservations) while } \\
\text { planning the trip. }\end{array}$ & 315 & 4.08 & 39.7 & 0.6 & 0.936 \\
\hline $\begin{array}{l}\text { Making travel and accommodation arrangements } \\
\text { for this trip was basically problem-free (e.g. travel } \\
\text { agents were knowledgeable, I was not put on } \\
\text { hold for long periods of time, the Festival website } \\
\text { was user-friendly). }\end{array}$ & 315 & 4.10 & 41.6 & 0.6 & 0.939 \\
\hline $\begin{array}{l}\text { The cost of the services provided by tourism } \\
\text { professionals in helping me with travel logistics } \\
\text { was reasonable and well worth it. }\end{array}$ & 315 & 3.91 & 31.4 & 1.6 & 0.654 \\
\hline $\begin{array}{l}\text { I was pleased with the quality of services } \\
\text { provided in transit to the Festival. }\end{array}$ & 315 & 3.95 & 32.7 & 1.0 & 0.944 \\
\hline $\begin{array}{l}\text { My travels to the Festival were basically } \\
\text { problem-free (e.g. the aeroplane seats were as } \\
\text { reserved, road signs and directions were clear, I } \\
\text { did not get lost, etc.). }\end{array}$ & 315 & 4.04 & 40.6 & 2.5 & 1.052 \\
\hline $\begin{array}{l}\text { The cost of travel to the Festival was reasonable } \\
\text { and well worth it. }\end{array}$ & 315 & 4.02 & 34.0 & 1.9 & 0.951 \\
\hline $\begin{array}{l}\text { Tourist services provided at the destination (e.g. } \\
\text { activities, tourist attractions, the Festival, } \\
\text { restaurants, accommodation) were } \\
\text { comprehensive and of high quality. These } \\
\text { services made the trip a richer experience. }\end{array}$ & 315 & 4.22 & 52.4 & 3.2 & 1.047 \\
\hline $\begin{array}{l}\text { Tourist services provided at the destination were } \\
\text { basically problem-free (e.g. accommodation } \\
\text { reserved was available at check-in time, correct } \\
\text { seats for shows were available as booked, food } \\
\text { was acceptable). }\end{array}$ & 315 & 4.15 & 46.0 & 4.4 & 1.061 \\
\hline $\begin{array}{l}\text { The cost of tourist services at the destination } \\
\text { was reasonable and well worth it }\end{array}$ & 315 & 3.94 & 33.0 & 5.1 & 1.063 \\
\hline $\begin{array}{l}\text { I was satisfied with the quality of the services } \\
\text { provided by those who assisted me on the way }\end{array}$ & 315 & 3.79 & 25.1 & 1.6 & 0.937 \\
\hline
\end{tabular}




\begin{tabular}{|l|c|c|c|c|c|}
\hline home. & & & & & \\
\hline $\begin{array}{l}\text { Planning for the return trip were basically } \\
\text { problem free. }\end{array}$ & 315 & 3.85 & 26.0 & 1.0 & 0.896 \\
\hline $\begin{array}{l}\text { Planning the cost of travel home from the } \\
\text { Festival was reasonable and well worth it. }\end{array}$ & 315 & 3.81 & 25.1 & 1.3 & 0.932 \\
\hline
\end{tabular}

Table 4 provides an exposition of the level of satisfaction for individual statements included in the measurement set for satisfaction with travel/tourism experiences. The statement 'One cannot afford to be spontaneous in everyday life. But one needs to be spontaneous once in a while. This trip allowed me to do just that - to be spontaneous' obtained the highest mean score (4.35) followed by 'On this trip, I felt far away from the drudgery of work' and 'I needed to get away from work and relax. This trip helped me to rejuvenate' (both with a mean score of 4.32). The lowest mean score (2.96) was for the statement 'On this trip, I was to sharpen my skills on a passionate hobby. This was very rewarding for me'.

Table 4: Satisfaction with travel/tourism experiences

\begin{tabular}{|l|c|c|c|c|c|}
\hline \multicolumn{7}{|c|}{ Satisfaction with travel/tourism experiences } \\
\hline \multicolumn{1}{|c|}{ Activity } & N & Mean & $\begin{array}{c}\text { Top-box } \\
\text { score }\end{array}$ & $\begin{array}{c}\text { Low-box } \\
\text { score }\end{array}$ & $\begin{array}{c}\text { Standard } \\
\text { deviation }\end{array}$ \\
\hline $\begin{array}{l}\text { In general, I was pleased with the quality of the } \\
\text { tourism services related to this trip. }\end{array}$ & 315 & 4.18 & 35.9 & 0.6 & 0.771 \\
\hline $\begin{array}{l}\text { The tourism services related to this trip were } \\
\text { basically problem-free. }\end{array}$ & 315 & 4.13 & 36.8 & 0.6 & 0.845 \\
\hline $\begin{array}{l}\text { The cost of tourism services related to this trip } \\
\text { was reasonable and well worth it. }\end{array}$ & 315 & 3.97 & 29.2 & 1.3 & 0.908 \\
\hline $\begin{array}{l}\text { On this trip, I felt free to do the kinds of things I } \\
\text { can't do at home. }\end{array}$ & 315 & 4.13 & 47.0 & 4.4 & 1.093 \\
\hline $\begin{array}{l}\text { On this trip, I felt free from the controls of other } \\
\text { people. I felt in control of my movements and } \\
\text { actions. }\end{array}$ & 315 & 4.19 & 54.9 & 4.1 & 1.129 \\
\hline On this trip, I felt free from the pressures of life. & 315 & 4.27 & 49.5 & 1.6 & 0.904 \\
\hline $\begin{array}{l}\text { On this trip, I felt far away from the drudgery of } \\
\text { work. }\end{array}$ & 315 & 4.32 & 52.7 & 0.6 & 0.879 \\
\hline $\begin{array}{l}\text { I needed to get away from work and relax. This } \\
\text { trip helped me to rejuvenate. }\end{array}$ & 315 & 4.32 & 55.2 & 0.6 & 0.908 \\
\hline $\begin{array}{l}\text { I was feeling overworked and emotionally } \\
\text { exhausted. This trip helped me to get away from } \\
\text { the stresses and strains of work. }\end{array}$ & 315 & 3.78 & 39.7 & 8.6 & 1.305 \\
\hline $\begin{array}{l}\text { On this trip, I became emotionally involved and } \\
\text { engaged with people and things. The experience } \\
\text { was very pleasant for me. }\end{array}$ & 315 & 3.68 & 30.5 & 7.9 & 1.245 \\
\hline $\begin{array}{l}\text { This trip allowed me to get close to my spouse, } \\
\text { children, relatives, and/or friends. It was very } \\
\text { worthwhile. }\end{array}$ & 315 & 4.00 & 34.0 & 3.5 & 0.992 \\
\hline $\begin{array}{l}\text { On this trip, I was able to re-establish a dwindling } \\
\text { relationship with people for whom I care a lot. }\end{array}$ & 315 & 3.59 & 28.3 & 10.5 & 1.275 \\
\hline $\begin{array}{l}\text { On this trip, I managed to do exciting things. I } \\
\text { experienced a lot of thrills. This experience has } \\
\text { been enriching. }\end{array}$ & 315 & 4.07 & 42.2 & 3.5 & 1.053 \\
\hline $\begin{array}{l}\text { On this trip, I established friendships with one or } \\
\text { more new people. This was exciting. I needed to } \\
\text { make some new friends. }\end{array}$ & 315 & 3.57 & 28.9 & 9.8 & 1.291 \\
\hline On this trip, I got involved in an exciting activity. I & 315 & 3.50 & 26.0 & 10.8 & 1.307 \\
\hline
\end{tabular}




\begin{tabular}{|l|c|c|c|c|c|}
\hline felt alive. & & & & & \\
\hline $\begin{array}{l}\text { On this trip, I was able to pursue a passionate } \\
\text { interest. This experience was thrilling. }\end{array}$ & 315 & 3.52 & 27.9 & 11.1 & 1.322 \\
\hline $\begin{array}{l}\text { On this trip, I had a chance to master a hobby. I } \\
\text { had wanted to do this for a long time but never } \\
\text { had the chance. }\end{array}$ & 315 & 2.92 & 21.3 & 22.5 & 1.463 \\
\hline $\begin{array}{l}\text { On this trip, I was to sharpen my skills on a } \\
\text { passionate hobby. This was very rewarding to } \\
\text { me. }\end{array}$ & 315 & 2.96 & 21.9 & 23.2 & 1.475 \\
\hline $\begin{array}{l}\text { On this trip, I felt spontaneous. This experience } \\
\text { has enriched me in ways I never expected. }\end{array}$ & 315 & 4.26 & 52.1 & 1.9 & 0.961 \\
\hline $\begin{array}{l}\text { One cannot afford to be spontaneous in } \\
\text { everyday life. But one needs to be spontaneous } \\
\text { once in a while. This trip allowed me to do just } \\
\text { that - to be spontaneous. }\end{array}$ & 315 & 4.35 & 54.3 & 1.3 & 0.887 \\
\hline $\begin{array}{l}\text { On this trip, I enjoyed getting to do things on the } \\
\text { spur of the moment. }\end{array}$ & 315 & 4.14 & 48.6 & 6.0 & 1.130 \\
\hline $\begin{array}{l}\text { All in all, I feel that this trip has enriched my life. I } \\
\text { am really glad I went on this trip. }\end{array}$ & 315 & 4.10 & 36.2 & 1.3 & 0.886 \\
\hline $\begin{array}{l}\text { On this trip, I accomplished my purpose of } \\
\text { visiting the Festival. This enriched me in some } \\
\text { ways. }\end{array}$ & 315 & 4.20 & 39.4 & 0.3 & 0.803 \\
\hline $\begin{array}{l}\text { This trip was rewarding to me in many ways. I } \\
\text { feel much better about things and myself after } \\
\text { this trip. }\end{array}$ & 315 & 4.22 & 41.3 & 0.6 & 0.811 \\
\hline
\end{tabular}

Table 5 provides an exposition of the levels of satisfaction for individual statements included in the measurement set assessing leisure life. The statement 'Leisure time after work is very important to me' obtained the highest mean score (4.64), followed by 'I am generally happy with my family situation' (4.35). The lowest mean score (3.81) was for the statement 'I am generally happy with my standard of living and financial situation'.

Table 5: Satisfaction with leisure life

\begin{tabular}{|l|c|c|c|c|c|}
\hline \multicolumn{7}{|c|}{ Satisfaction with leisure life } \\
\hline \multicolumn{1}{|c|}{ Activity } & N & Mean & $\begin{array}{c}\text { Top-box } \\
\text { score }\end{array}$ & $\begin{array}{c}\text { Low-box } \\
\text { score }\end{array}$ & $\begin{array}{c}\text { Standard } \\
\text { deviation }\end{array}$ \\
\hline I do things that are fulfilling when I am off work. & 315 & 4.16 & 40.0 & 1.6 & 0.898 \\
\hline $\begin{array}{l}\text { Lately, I have been feeling very good about the } \\
\text { way I spend my leisure time after work. }\end{array}$ & 315 & 4.07 & 38.4 & 1.6 & 0.980 \\
\hline Leisure time after work is very important to me. & 315 & 4.64 & 70.5 & 1.0 & 0.655 \\
\hline $\begin{array}{l}\text { Recently, I have been spending quality leisure } \\
\text { time in general (e.g. going on vacations, relaxing } \\
\text { around the house, enjoying a hobby, visiting } \\
\text { shopping centres). I am the kind of person who } \\
\text { knows how to enjoy leisure time anytime and } \\
\text { anywhere. }\end{array}$ & 315 & 3.84 & 37.8 & 6.7 & 1.223 \\
\hline $\begin{array}{l}\text { I am generally happy with the quality of my } \\
\text { leisure time. }\end{array}$ & 315 & 4.17 & 38.7 & 0.6 & 0.836 \\
\hline I am generally happy with my job. & 315 & 4.04 & 39.4 & 1.0 & 0.996 \\
\hline I am generally happy with my family situation. & 315 & 4.35 & 54.9 & 1.3 & 0.895 \\
\hline I am generally happy with my personal health. & 315 & 4.23 & 48.9 & 1.3 & 0.957 \\
\hline $\begin{array}{l}\text { I am generally happy with the relationships I } \\
\text { have with people such as relatives, friends, and }\end{array}$ & 315 & 4.09 & 43.5 & 3.5 & 1.076 \\
\hline
\end{tabular}




\begin{tabular}{|l|c|c|c|c|c|}
\hline neighbours. & & & & & \\
\hline $\begin{array}{l}\text { I am generally happy with my community and } \\
\text { neighbourhood. }\end{array}$ & 315 & 4.04 & 37.5 & 2.9 & 1.015 \\
\hline $\begin{array}{l}\text { I am generally happy with my standard of living } \\
\text { and financial situation. }\end{array}$ & 315 & 3.81 & 31.4 & 4.4 & 1.117 \\
\hline
\end{tabular}

Table 6 reports the levels of satisfaction for individual statements included in the measurement set for satisfaction with life in general. The statement 'I lead a meaningful and fulfilling life' obtained the highest mean score (4.40). The lowest mean score (4.27) was for the statement 'I am satisfied with life in general'.

Table 6: Satisfaction with life in general

\begin{tabular}{|c|c|c|c|c|c|}
\hline \multicolumn{6}{|c|}{ Satisfaction with life in general } \\
\hline Activity & $\mathbf{N}$ & Mean & $\begin{array}{l}\text { Top-box } \\
\text { score }\end{array}$ & $\begin{array}{l}\text { Low-box } \\
\text { score }\end{array}$ & $\begin{array}{l}\text { Standard } \\
\text { deviation }\end{array}$ \\
\hline I am satisfied with life in general. & 315 & 4.27 & 42.2 & 0.6 & 0.767 \\
\hline I am generally happy with my life. & 315 & 4.29 & 42.5 & 0.6 & 0.754 \\
\hline $\begin{array}{l}\text { Although I have my ups and downs, in general I } \\
\text { feel good about my life. }\end{array}$ & 315 & 4.31 & 44.4 & 0.3 & 0.747 \\
\hline I lead a meaningful and fulfilling life. & 315 & 4.40 & 53.3 & 1.0 & 0.777 \\
\hline
\end{tabular}

Table 7 provides the overall mean scores for each of the measurement sets. Respondents were asked to rate their level of agreement with statements - on a scale from 1 to 5 , where 1 is 'strongly disagree' and 5 is 'strongly agree'. The researcher considers a mean score of more than 3.00 as indicative that respondents are satisfied. The mean score for all measurement sets is well above the 3.00 level. It can therefore be said that respondents are satisfied with travel/tourism services and experiences related to Aardklop, and with their leisure time and with life in general.

Table 7: Overall mean scores for satisfaction in each measurement set

\begin{tabular}{|l|c|}
\hline \multicolumn{2}{|c|}{ Overall satisfaction } \\
\hline \multicolumn{1}{|c|}{ Measurement set } & Score \\
\hline Satisfaction with travel/tourism services (12 items) & 3.9876 \\
\hline Satisfaction with travel/tourism experiences (24 items) & 3.9321 \\
\hline Satisfaction with leisure life (11 items) & 4.1302 \\
\hline Satisfaction with life in general (4 items) & 4.3167 \\
\hline
\end{tabular}

\section{Hypothesis Testing}

Significance testing was conducted in order to determine whether or not the different groups of respondents (classed by gender, dietary requirements, qualifications, population group, and home region) differ significantly in the overall means score calculated for each measurement set (Hypotheses 1 to 5). 
To determine whether or not significant differences exist between the mean responses of two groups (male and female) the Independent Sample T-test was conducted. Since the researchers relied on a $95 \%$ level of confidence, or a $5 \%$ level of significance $(\alpha=0.05)$, a $p$-value of less than or equal to 0.05 indicates a significant difference between the means in terms of the Independent Sample T-test.

An analysis of variance (ANOVA) and the Kruskal-Wallis Test were performed to determine whether or not significant differences exist between the mean responses of more than two groups (dietary requirements, qualifications, population group, and home region). The Kruskal-Wallis Test, a nonparametric test, was used since at least one of the groups contains fewer than 30 responses and a normal distribution of results cannot be assumed (Tustin, Lighthelm, Martins \& Van Wyk, 2005:624625; Diamantopoulos \& Schlegelmilch, 1997:181-182). Duncan's Multiple Range Test was used as Post Hoc Test to identify the groups between which significant differences can be observed when equal variances can be assumed. Duncan's Multiple Range Test presents the means of groups which are significantly different in different subsets, in table format (Burns \& Bush, 1999:561). Dunnet's T3 was used as Post Hoc Test to identify the groups between which significant differences can be observed when equal variances cannot be assumed (Eiselen, Uys \& Potgieter, 2005:124).

The results of the significance testing are as follows (detailed explanations and relevant tables are only included where significant differences were found to exist):

\section{Hypothesis 1}

Male and female respondents do not differ in their levels of satisfaction with travel/tourism services, travel/tourism experiences, their leisure life, and life in general $\left(\mathrm{H}_{1 \mathrm{a}}\right.$ to $\left.\mathrm{H}_{1 \mathrm{~d}}\right)$.

\section{Hypothesis 2}

Respondents with different dietary requirements do not differ in their levels of satisfaction with travel/tourism services, travel/tourism experiences, their leisure life, and life in general $\left(\mathrm{H}_{2 \mathrm{a}}\right.$ to $\left.\mathrm{H}_{2 \mathrm{~d}}\right)$.

\section{Hypothesis 3}

Respondents with different qualifications do not differ in their levels of satisfaction with travel/tourism services, travel/tourism experiences, their leisure life, and life in general $\left(\mathrm{H}_{3 \mathrm{a}}\right.$ to $\left.\mathrm{H}_{3 \mathrm{~d}}\right)$.

\section{Hypothesis 4}

Table 8 indicates whether or not significant differences exist between population groups when it comes to overall mean scores for the measurement sets representing satisfaction with travel/tourism services, travel/tourism experiences, leisure life, and life in general.

Table 8: Significance testing of the overall mean scores for satisfaction of respondents from different population groups

\begin{tabular}{|l|c|c|}
\hline \multicolumn{1}{|c|}{ Measurement set } & $\begin{array}{c}\text { ANOVA (p- } \\
\text { value) }\end{array}$ & $\begin{array}{c}\text { Kruskal- } \\
\text { Wallis Test } \\
\text { (p-value) }\end{array}$ \\
\hline Satisfaction with travel/tourism services (12 items) & 0.141 & 0.110 \\
\hline Satisfaction with travel/tourism experiences (24 items) & 0.238 & 0.248 \\
\hline Satisfaction with leisure life (11 items) & $0.006^{*}$ & $0.007^{*}$ \\
\hline Satisfaction with life in general (4 items) & 0.021 & 0.094 \\
\hline
\end{tabular}

* Significant differences indicated by both parametric and non-parametric tests

It is evident from Table 8 that there are significant differences in the overall mean scores for the 'Satisfaction with leisure life' measurement set between at least two of the different population groups $\left(\mathrm{H}_{4 c}\right)$. The overall mean scores for at least two population groups are significantly different (ANOVA 
and Kruskal-Wallis Test p-values are less than 0.05: 0.006 and 0.007, respectively). Equal variances can be assumed since the p-value for the Test of Homogeneity of Variances for 'Satisfaction with leisure life' is greater than 0.05 (0.112) and thus Duncan's Multiple Range Test may be used as Post Hoc Test. This test indicates a significant difference between the overall mean scores for whites (4.1674), blacks (3.7102), and Indians (4.2381).

It can therefore be concluded that respondents from different population groups do not differ in their levels of satisfaction with travel/tourism services, travel/tourism experiences, and life in general $\left(\mathrm{H}_{4 a}\right.$, $\mathrm{H}_{4 b}$, and $\mathrm{H}_{4 \mathrm{~d}}$ ), but that blacks indicate a significantly lower score than whites and Indians for satisfaction with their leisure life $\left(\mathrm{H}_{4 \mathrm{c}}\right)$.

\section{Hypothesis 5}

Table 9 indicates whether or not significant differences exist in the overall mean scores for measurement sets representing satisfaction of respondents from different regions with travel/tourism services, travel/tourism experiences, their leisure life, and life in general.

Table 9: Significance testing of the overall mean scores for satisfaction of respondents from different regions

\begin{tabular}{|l|c|c|}
\hline \multicolumn{1}{|c|}{ Measurement set } & $\begin{array}{c}\text { ANOVA (p- } \\
\text { value) }\end{array}$ & $\begin{array}{c}\text { Kruskal- } \\
\text { Wallis Test } \\
(\mathbf{p} \text {-value })\end{array}$ \\
\hline Satisfaction with travel/tourism services (12 items) & 0.003 & 0.071 \\
\hline Satisfaction with travel/tourism experiences (24 items) & 0.045 & 0.106 \\
\hline Satisfaction with leisure life (11 items) & $0.041^{*}$ & $0.016^{*}$ \\
\hline Satisfaction with life in general (4 items) & 0.635 & 0.728 \\
\hline
\end{tabular}

* Significant differences indicated by both parametric and non-parametric tests

It is evident from Table 9 that the overall mean scores for the 'Satisfaction with leisure life' measurement set for at least two regional groups are significantly different (ANOVA and KruskalWallis Test $p$-values are less than 0.05: 0.041 and 0.016, respectively). Equal variances can be assumed since the p-value for the Test of Homogeneity of Variances for 'Satisfaction with leisure life' is greater than $0.05(0.134)$, and thus Duncan's Multiple Range Test can be used. The test indicates that the overall mean score for the 'Satisfaction with leisure life' measurement set for respondents from the Free State (3.8805) is significantly different from the overall mean score for respondents from Kwa-Zulu Natal (4.3636) and the Northern Cape (4.3864).

It can therefore be concluded that respondents from different regions do not differ in their levels of satisfaction with travel/tourism services, travel/tourism experiences, and life in general $\left(\left(\mathrm{H}_{5 a}, \mathrm{H}_{5 b}\right.\right.$, and $\mathrm{H}_{5 \mathrm{~d}}$ ), but that respondents from the Free State indicate a significantly lower level of satisfaction with their leisure life than do respondents from Kwa-Zulu Natal and the Northern Cape $\left(\mathrm{H}_{5 c}\right)$.

\section{IMPLICATIONS}

The tourism industry faces unique challenges in providing services in the South African context. Major events such as arts festivals are becoming very popular means of recreation: the industry should focus on offering good services tailored to the destination where an event takes place, and this will have an effect on tourists' satisfaction levels with tourism services and experiences, their leisure life, and their life in general. All of this ultimately influences the quality of life of people. By improving travel/tourism services and experiences, organizers of festivals and businesses which cater for tourists can improve satisfaction - which will ultimately lead to return visits, greater profits, and happier people all round. 
Differences identified between the different groups of respondents in the study should alert Festival organizers and businesses to the fact that they should take cognizance of the differences between respondents, and should consider developing unique marketing strategies to attract and retain these different groupings.

\section{ORIGINALITY/VALUE}

This research project focuses on the measurement of satisfaction levels in relation to quality of life issues of tourists attending an arts festival. This type of research has not been conducted in South Africa before, and the results might be used to contribute to the broader knowledge of interested parties, such as the tourism industry and arts festival managers. It can alert businesses to their role in customer satisfaction - indeed, in their quality of life. Tourists attending arts festivals are also not a homogonous set, as they differ demographically and exhibit differences in levels of satisfaction with quality of life issues. It is therefore important for businesses involved in the Festival to offer services and experiences tailor-made for the different segments of the market attending it.

\section{PROPOSALS FOR FURTHER RESEARCH}

This survey could be conducted at the three other major arts festivals in South Africa: the Grahamstown National Arts Festival, the Klein Karoo National Arts Festival, and the Innie-bos National Arts Festival, in order to draw comparisons between the levels of satisfaction experienced at the different festivals. Significant differences between different groups of respondents (population group, home region, etc.) in their levels of satisfaction could be explored in order to determine strategies to appeal to the various groups attending arts festivals. Finally, data from the present study may also be used to validate the measurement instrument used in it - that of Neal et al. (1999:156 \& 2004:245).

\section{CONCLUSION}

Despite the obvious need for further research, the authors feel that the current study contributes to research into quality of life. The research indicates that most of the tourists at Aardklop strongly agree their experience of the Festival was positive.

\section{REFERENCES}

Bailey TC, Eng W, Frisch MB \& Snyder CR. 2007. Hope and optimism as related to life satisfaction. Journal of positive psychology, 2:168-175.

Bennet JA. 1998. Managing tourism services. $3^{\text {rd }}$ ed. Pretoria: Van Schaik.

Bennet JA, Jooste CJ \& Strydom L. 2005. Managing tourism services. $5^{\text {th }}$ ed. Pretoria: Van Schaik.

Burns AC \& Bush RF. 2000. Marketing research. $3^{\text {rd }}$ ed. Upper Saddle River, New Jersey: Prentice Hall.

Campbell A, Converse PE \& Rodgers WL. 1976. The quality of American life. $1^{\text {st }}$ ed. New York: Russell Sage Foundation.

Clark LA \& Watson D. 1988. Mood and the mundane: relations between daily life events and selfreported mood. Journal of personality and social psychology, 54:296-308.

Clawson M \& Knetsch JL. 1971. Economics of Outdoor Recreation. Baltimore \& London: Johns Hopkins.

De Rue DS, llies R, Ilgen R, Johnson MD, Schwind KM \& Wagner DT. 2007. When can employees have a family life? the effects of daily workload and affect on work-family conflict and social behaviors at home. Journal of applied psychology, 92:1368-1379. 
Diamantopoulos A \& Schlegelmilch BB. 1997. Taking the fear out of data analysis. London: The Dryden Press.

Eiselen R, Uys T \& Potgieter T. 2005. Analysing Survey Data using SPSS13. $3^{\text {rd }}$ ed. Statkon: University of Johannesburg.

Getz D. 2000. Defining the field of event management. Event management, 6:1-3.

Hair JF(Jr.), Anderson RE, Tatham RL \& Black WC. 1998. Multivariate data analysis. $5^{\text {th }}$ ed. Upper Saddle River, New Jersey: Prentice-Hall.

Khaneman D, Kreuger AB, Schkade DA, Schwartz N \& Stone AA. 2004. A survey method for characterizing daily life experience: The day reconstruction method. Science, 306:1776-1780.

Neal JD, Sirgy MJ \& Uysal M. 1999. 'The role of satisfaction with leisure travel/tourism services and experiences in satisfaction with leisure life and overall life' and overall life'. Journal of business research, 44:153-164.

Neal JD, Sirgy MJ \& Uysal M. 2004. Measuring the effect of tourism services on travellers' quality of life: further validation. Social indicators research, 69:243-277.

Ryan C. 1991. Recreational tourism: a social science perspective. $5^{\text {th }}$ ed. London: Routledge.

Saayman M. 2006. Socio-Demographics and visiting patterns of arts festivals in South Africa. Event management, 9:211-222.

Saayman M \& Saayman A. 2006. Ekonomiese impak en profiel van besoekers aan die Aardklop Nasionale Kunstefees: 2006. Potchefstroom: Instituut vir Toerisme en Vryetydstudies.

Saayman M \& Ferreira M. 2007. Ekonomiese impak en profiel van besoekers aan die Aardklop Nasionale Kunstefees: 2006. Potchefstroom: Instituut vir Toerisme en Vryetydstudies.

Tustin DH, Ligthelm AA, Martins JH \& Van Wyk HdeJ. 2005. Marketing Research in Practice. Pretoria: Unisa Press.

Watson D. 1988. Intraindividual and interindividual analyses of positive and negative affect: their relation to health complaints, perceived stress, and daily activities. Journal of personality and social psychology, 54:1020-1030.

Watson D. 2000. Mood and temperament $1^{\text {st }}$ ed. New York: Guilford Press.

West SG, Finch JF \& Curran PJ. 1995. 'Structural equation models with non-normal variables: problems and remedies'. (In Hoyle, R. (ed.). Structural equation modelling: concepts, issues and applications. Newbury Park, California: Sage. 